\title{
Model Analysis of Motorcycle Suspension System Using the Fourth Order of Runge-Kutta Method
}

\section{Analisis Model Sistem Suspensi Sepeda Motor Dengan Metode Runge-Kutta Orde Empat}

\author{
Umi Nurofi'atin*, Agus Maman Abadi \\ Jurusan Matematika, FMIPA Universitas Negeri Yogyakarta, Yogyakarta, 55281, Telp \\ (0274)550846 \\ *uminurofiatin@gmail.com
}

\begin{abstract}
The suspension system is part of motorcycle that serves to absorb vibration and shocks of the road surface so as to improve the safety and comfort while driving. Motorcycle typically use double shockbreaker system which analogous to a two-spring system arranged in parallel. The aim of this researh is to analyze the model of the model of double shockbreaker motorcycle suspension system that working without outside force using passive suspension system. The data used are from damper tester experiment, then model analyzed using analytical method and the fourth order of numerical RungeKutta method. This research use shockbreaker observation datas that is the measurment data of spring constant and damping constant by performing damper tester using 4 different loads. The process model analysis using Matlab R2013a. Input variables are spring constant, damping constant, and the mass of the load. Methods of analysis using analytical method and the fourth order of Runge-Kutta method. While the resulting outputs are 2 spring constants, change the length of the spring, damping ratio, the optimal damping of the suspension, and the spring deflection chart against time. This model motorcycle suspension system uses solution of differential equations for the under damped suspension condition, that is the suspension system will be insulated a few moments before reaching the equilibrium position. Therefore, the resulting damping rate of the motorcycle is not optimal yet. This study found the optimal damping for each model of the suspension system. The level of accuracy of the fourth order of runge-kutta method for model analysis of the suspension system is quite high with error $<0.1$ and the timing of analysis is faster than the analytic method. Future research may use other methods or other input variables for more accurate analysis results.
\end{abstract}

Keywords: Motorcycle, Suspension System, The Damping Rate, Damper Tester, The Fourth Order Of Runge-Kutta Method

\footnotetext{
Abstrak

Sistem suspensi adalah bagian sepeda motor yang berfungsi menyerap getaran dan kejutan dari permukaan jalan sehingga meningkatkan keamanan dan kenyamanan saat berkendaraan. Sepeda motor yang menggunakan sistem double shockbreaker yang dianalogikan dengan sistem dua pegas yang disusun secara paralel. Penelitian ini bertujuan untuk menganalisis model sistem suspensi sepeda motor double shockbreaker bekerja tanpa gaya luar menggunakan sistem suspensi pasif. Data yang digunakan berasal dari percobaan damper tester, kemudian model dianalisis menggunakan metode analitik dan Runge-Kutta orde empat secara numerik. Penelitian ini menggunakan data 
pengamatan shockbreaker yaitu data pengukuran konstanta pegas dan konstanta redaman melakukan damper tester menggunakan 4 beban yang berbeda. Proses analisis model sistem suspensi menggunakan Matlab R2013a. Variabel input yaitu konstanta pegas, konstanta redaman, dan massa beban. Metode analisis menggunakan metode analitik dan metode Runge-Kutta orde empat. Sedangkan output yang dihasilkan adalah konstanta 2 pegas, perubahan panjang pegas, rasio redaman, redaman optimal suspensi, dan grafik defleksi pegas terhadap waktu. Model sistem suspensi sepeda motor ini menggunakan solusi persamaan diferensial untuk kondisi suspensi under damped, yaitu kondisi sistem suspensi akan berisolasi beberapa saat sebelum mencapai posisi kesetimbangan. Oleh karena itu, mengakibatkan tingkat redaman sepeda motor yang terjadi belum optimal. Penelitian ini menemukan redaman optimal untuk setiap model sistem suspensi. Tingkat keakuratan metode Runge-Kutta orde empat untuk analisis model suspensi cukup tinggi dengan galat $<0,1$ dan waktu analisis lebih cepat daripada metode analitik. Penelitian selanjutnya dapat menggunakan metode atau variabel input lain untuk hasil analisis lebih akurat.

Kata kunci: Sepeda Motor, Sistem Suspensi, Tingkat Redaman, Damper Tester, Metode Runge-Kutta Orde Empat

\section{Pendahuluan}

Sistem suspensi adalah bagian sepeda motor yang berfungsi menyerap getaran dan kejutan dari permukaan jalan sehingga meningkatkan keamanan, kenyamanan, dan stabilitas berkendaraan (Preceliunas, 2005). Oleh karena itu, pengembangan desain suspensi diperlukan untuk mendapatkan redaman optimal yang sesuai untuk setiap kendaraan sepeda motor.

Suspensi terdiri dari dua komponen utama, pegas dan shock absorber. Pegas berfungsi untuk menyerap dan meredam kejutan permukaan jalan, pegas harus fleksibel akan tetapi jika terlalu fleksibel dapat mengganggu kenyamaan dalam berkendara, sehingga memerlukan komponen peredam atau shock absorber untuk meredam getaran pegas (Wakid, 2011)

Sistem suspensi yang umum diterapkan pada kendaraan ada dua yaitu sistem suspensi pasif dan sistem suspensi aktif. Sistem suspensi pasif adalah sistem suspensi dengan konstanta pegas dan konstanta redaman dianggap konstan, tidak dipengaruhi oleh kondisi jalan dan laju kendaraan. Sistem suspensi aktif adalah sistem suspensi yang memperhitungkan kondisi jalan dan laju kendaraan untuk mengontrol konstanta pegas dan konstanta redaman yang dibutuhkan (Sutranta dan Sampurno, 2010).

Berdasarkan nilai konstanta redaman, sistem suspensi dibagi menjadi tiga kriteria yaitu sistem suspensi under damped, over damped, 
dan critically damped. Sistem suspensi under damped adalah kondisi dimana pegas akan bergerak naik turun melanjutkan gerakan awal selama beberapa saat sebelum akhirnya mencapai posisi kesetimbangan, sistem suspensi over damped adalah kondisi dimana pegas tidak akan bergerak naik turun sama sekali, sedangkan Sistem suspensi critically damped adalah kondisi dimana pegas mencapai posisi kesetimbangan dengan cepat tanpa terjadi penyusutan pegas (Jazar, 2008).

Sistem suspensi dapat dianalogikan sebagai sistem pegas teredam. Suspensi sepeda motor dengan sistem mono shockbreaker dapat dianalogikan dengan sistem satu pegas dan satu beban, sedangkan sistem double shockbreaker dapat dianalogikan dengan sistem dua pegas yang disusun secara paralel dan satu beban. Setiap kendaraan memiliki sistem suspensi yang berbeda sesuai dengan kegunaan sepeda motor, sehingga tingkat kenyamanan yang dirasakan penumpang juga berbeda (Pauliza, 2008).

Sistem pegas teredam pada umumnya dimodelkan secara matematika menggunakan persamaan diferensial. Persamaan diferensial merupakan model matematika dari fenomena atau masalah perubahan yang berkaitan dengan dunia nyata. Secara matematis, penelitian terhadap perubahan menghasilkan persamaan yang memuat turunan atau derivatif dari suatu fungsi.

Penyelesaian persamaan diferensial dapat diselesaikan dengan metode numerik, yaitu untuk mendapatkan aproksimasi untuk solusi eksak dari sebuah persamaan diferensial. Beberapa metode numerik yang sering digunakan untuk penyelesaian persamaan diferensial adalah metode Euler, metode Heun, metode deret Taylor, metode RungeKutta, dan metode banyak-langkah (Munir, 2010).

Metode Runge-Kutta adalah metode untuk memecahkan masalah nilai awal persamaan diferensial. Metode Runge-Kutta dimulai dari orde yang terkecil yaitu metode Runge-Kutta Orde dua, kemudian dilanjutkan dengan orde yang lebih tinggi (Atkinson dkk, 2009).

Metode Runge-Kutta banyak digunakan dalam penyelesaian persamaan diferensial karena metode ini relatif sederhana dan cukup akurat dibanding metode Euler. Metode 
Runge-Kutta orde empat adalah metode yang paling sering digunakan untuk mengaproksimasi solusi masalah nilai awal dalam persamaan diferensial orde satu maupun orde dua (Kartono, 2012).

Pada proses pemodelan sistem suspensi perlu dilakukan pengambilan data terhadap shockbreaker, untuk merancang shock absorber pada sistem suspensi sepeda motor. Dalam proses pengambilan data dapat dilakukan dengan cara suspensi/shockbreaker sepeda motor dikenai beban yang berbeda-beda. Sebagaimana yang dilakukan dalam penelitian Martande dkk (2013) untuk membuat desain suspensi sepeda motor. Penelitian lain yang melakukan pengambilan data untuk membuat desain shock absorber adalah penelitian Bhasha dkk (2017) yang menggunakan variabel massa beban, dan jenis suspensi untuk merancang desain suspensi sepeda motor.

Dalam analisis data menggunakan penerapan metode Runge-Kutta orde empat, telah dilakukan pada analisis model getaran pegas teredam yaitu antara lain penelitian yang dilakukan oleh Ika (2013) dan Renny (2015) mendapatkan kesimpulan bahwa metode Runge-Kutta orde empat baik dalam menyelesaikan model pegas teredam. Pegas teredam merupakan analogi dari sistem suspensi kendaraan.

Penelitian terhadap model dan analisis sistem suspensi telah banyak dilakukan, antara lain penelitian Fauzi (2017), Ayu (2017), dan Muhamad (2017), namun di dalam penelitianpenelitian tersebut dilakukan terhadap kendaraan mono shockbreaker. Penelitian sistem suspensi double shockbreaker pada sepada motor pernah dilakukan oleh Ismi (2012) dengan menggunakan metode multiple time scale dan divisualisaikan dengan Maple. Penelitian ini bersifat teoritis karena tidak disertai dengan analisis terhadap obyek suspensi secara langsung.

Dalam penelitian ini analisis model sistem suspensi sepeda motor dengan sistem suspensi double shockbreaker berbeda dengan penelitian yang sudah dilakukan oleh penelitipeneliti sebelumnya, yaitu sistem suspensi bekerja tanpa gaya luar menggunakan prinsip sistem suspensi pasif, data yang digunakan berasal dari percobaan damper tester, model dianalisis menggunakan metode analitik dan Runge-Kutta orde empat, kemudian dicari redaman optimal dari sistem suspensi berdasarkan massa yang 
digunakan, hasil penyelesaian metode Runge-Kutta orde empat dibandingkan dengan metode analitik untuk mengetahui keakurat metode RungeKutta orde empat, dan hasilnya divisualisakan dengan menggunakan Matlab R2013a.

Penelitian ini bertujuan menentukan solusi persamaan diferensial dari model matematika sistem suspensi sepeda motor, mengetahui tingkat redaman dari sistem suspensi sepeda motor, dan mengetahui tingkat keakuratan metode Runge-Kutta orde empat unrtuk menyelesaikan model sistem suspensi sepeda motor secara numerik.

\section{Bahan dan Metode}

Penelitan ini menggunakan data primer, hasil pengamatan percobaan terhadap shockbreaker pada sepeda motor dengan sistem suspensi double shockbreaker menggunakan langkahlangkah damper tester, yaitu menekan bagian suspensi belakang kebawah dengan cara memberi beban yang pada suspensi secara bergantian; pengujian manual dilakukan oleh 2 orang, orang pertama sebagai operator dan orang kedua sebagai pengamat; melakukan langkah pertama sebanyak 3 kali; mengamati pergerakan naik turun/osilasi pegas dan damper yang terjadi kemudian mencatat perubahan panjang dan waktu perubahan atau waktu oksilasi; dan men-ilustrasikan pergerakan naik turun pegas sesuai perkiraan pengamatan yang dilakukan (Denton, 2012).

Data yang akan digunakan dalam proses analisis adalah massa $(m)$ beban, nilai konstanta $\operatorname{pegas}(k)$ dan konstanta redaman(c) dari shockbreaker sepeda motor, percobaan damper tester menggunakan 4 beban dengan massa secara berturut-turut $10 \mathrm{~kg}, 25 \mathrm{~kg}, 53 \mathrm{~kg}$, dan 61kg.Setelah itu data dianalisis menggunakan metode analitik dan metode Runge-Kutta secara numerik. Berikut adalah langkah-langkah analisis model sistem suspensi sepeda motor:

1. Menentukan Model Sistem Suspensi Sepeda Motor

Model sistem suspensi sepeda motor pada penelitian ini dianalogikan dengan sistem dua pegas yang disusun secara paralel dengan satu beban, sehingga akan didapatkan suatu persamaan diferensial orde dua homogen. Hal ini dapat berlaku dengan syarat awal yang digunakan untuk menunjukkan keadaan awal sistem yaitu, posisi pegas awal sebelum 
dikenai beban diasumsikan dengan $y_{0}=1$ dan diberikan kecepatan awal $v_{0}=0 \mathrm{~km} / \mathrm{jam}$ kerena sistem suspensi yang digunakan adalah sistem suspensi pasif.

2. Menyelesaikan Model Metode Runge-Kutta Orde Empat

Model sistem suspensi sepeda motor akan diselesaikan dengan metode Runge-Kutta orde empat untuk masalah nilai awal persamaan diferensial orde dua. Analisis metode Runge-Kutta orde empat untuk model sistem suspensi sepeda motor dengan langkah-langkah sebagai berikut:

a. Persamaan diferensial biasa orde dua direduksi menjadi sistem persamaan diferensial linier orde satu.

b. Partisi ukuran langkah metode Runge-Kutta orde empat ditentukan pada interval $t \in[0,10]$.

3. Analisis Model

Software yang digunakan untuk menyelesaikan persamaan model sistem suspensi sepeda motor adalah Matlab R2013a. Prosedur yang akan dilakukan pada langkah ini adalah menentukan input dan output sebagai berikut :

a. Input
Nilai-nilai parameter input yaitu $(k)$ adalah konstanta pegas, (c) adalah konstanta redaman, dan $(m)$ adalah massa beban.

b. Output

Output yang dihasilkan dari simulasi ini berupa nilai konstanta $2 \operatorname{pegas}\left(k_{t o t}\right)$, perubahan panjang $(x)$, rasio redaman $(\xi), \quad$ redaman optimal $\left(c_{c}\right)$ dan grafik posisi pegas terhadap waktu.

\section{Menentukan Redaman Optimal}

Tahap ini akan menunjukkan redaman optimal/kritis yang sesuai untuk sistem suspensi sepeda motor. Menurut Karyasa, besar redaman kritis dapat ditentukan dengan persamaan(1):

$$
c_{c}=2 m \sqrt{\frac{k}{m}}
$$

atau

$$
c_{c}^{2}=4 m k
$$

dengan :

$c_{c}=$ konstanta redaman kritis $(\mathrm{Ns} / \mathrm{cm})$

$m=$ massa beban $(\mathrm{kg})$

$k=$ konstanta pegas $(\mathrm{N} / \mathrm{cm})$

\section{Pengujian Model Sistem Suspensi}

Tahap ini membandingkan hasil model dengan metode Runge-Kutta orde empat terhadap metode analitik dengan cara memberikan nilai 
parameter-parameter pada sistem suspensi yaitu massa beban, nilai konstanta pegas, nilai konstanta redaman. Langkah berikutnya dilakukan pengukuran terhadap tingkat keakuratan metode Runge-Kutta orde empat dengan cara mencocokkan hasil metode Runge-Kutta orde empat terhadap metode analitik, menghitung waktu analisis dari kedua metode, dan menunjukkan kriteria redaman dari sistem suspensi sepeda motor berdasarkan nilai damping ratio. Menurut Karyasa, dari percobaan yang dilakukan di atas dapat ditentukan besar damping ratio dengan persamaan

$$
\xi=\frac{c}{c_{c}}
$$

dengan :

$\xi=$ damping rasio

$c=$ konstanta redaman $(\mathrm{Ns} / \mathrm{cm})$

$c_{c}=$ konstanta redaman kritis $(\mathrm{Ns} / \mathrm{cm})$

Diagram alir untuk proses analisis model sistem suspensi sepeda motor dengan metode Runge-Kutta orde empat dapat dilihat pada Gambar 1.

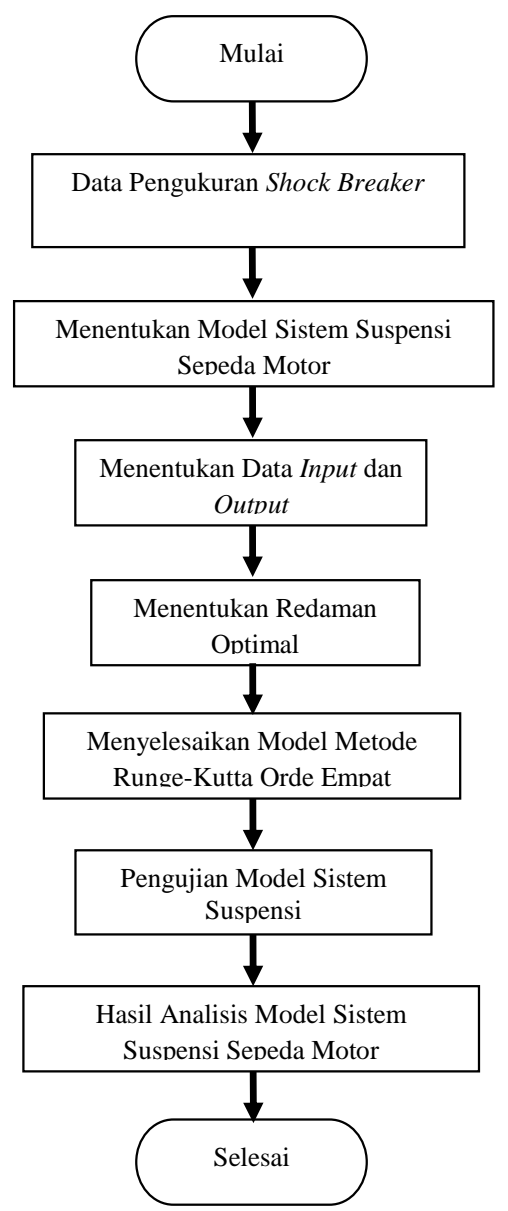

Gambar 1. Diagram Alir Proses Analisis Model Sistem Suspensi Sepeda Motor Dengan Metode Runge-Kutta Orde Empat.

\section{Pembahasan}

\section{Model Sistem Supensi Sepeda Motor}

\section{Model Pegas Teredam}

Gaya yang bekerja pada sistem pegas teredam, persamaan (3):

$$
m \frac{d^{2} y}{d t^{2}}+c \frac{d y}{d t}+k y=0
$$

\section{Model Sistem Suspensi Sepeda Motor}

Persamaan model sistem suspensi sepeda motor dianalogikan dengan gaya pada sistem pegas teredam akan tetapi model sistem suspensi sepeda motor Model Analysis of Motorcycle Suspension System Using the Fourth Order of Runge-Kutta Method 
menggunakan sistem pegas paralel, maka persamaan(3) menjadi persamaan (4):

$$
m \frac{d^{2} y}{d t^{2}}+c \frac{d y}{d t}+k_{t o t} y=0
$$

dengan $m$ adalah massa beban, $c$ adalah konstanta redaman, dan $k_{\text {tot }}$ adalah konstanta pegas, dengan $k_{\text {tot }}=k_{1}+$ $k_{2}, k_{1}$ adalah pegas suspensi sebelah kiri, $k_{2}$ adalah pegas suspensi sebelah kanan (posisi sesuai kondisi mengendarai sepeda motor).

\section{Solusi Model Sistem Suspensi Sepeda Motor}

\section{Metode Analitik}

Solusi metode analitik untuk persamaan(4) model suspensi sepeda motor, dengan diambil $p=\frac{c}{2 m}$, $q=\sqrt{\frac{k_{t o t}}{m}}$, dan $D=p^{2}-q^{2}$, adalah sebagai berikut

$$
\left\{\begin{array}{c}
y_{1}=e^{(-p) t} \cos (\sqrt{D} t)+\frac{p}{\sqrt{D}} e^{(-p) t} \sin (\sqrt{D} t), \\
\text { untuk } D<0 \\
y_{2}=A e^{(-p+\sqrt{D}) t}+B e^{(-p-\sqrt{D}) t}, \text { untuk } D>0 \\
y_{3}=(1+p t) e^{-p t}, \text { untuk } D=0
\end{array}\right.
$$

dengan:

$$
\begin{aligned}
y_{1}= & \text { Persamaan model sistem } \\
& \text { suspensi sepeda motor pada } \\
& \text { kondisi under damped. } \\
y_{2}= & \text { Persamaan model sistem } \\
& \text { suspensi sepeda motor pada } \\
& \text { kondisi over damped. }
\end{aligned}
$$

$y_{3}=$ Persamaan model sistem suspensi sepeda motor pada kondisi critically damped.

\section{Metode Runge-Kutta Orde Empat}

Persamaan model sistem suspensi sepeda motor pada penelitian ini merupakan persamaan diferensial linear orde dua. Oleh karena itu dapat diselesaikan dengan menggunakan metode Runge-Kutta orde empat, dengan cara mereduksi persamaan(4) menjadi sistem persamaan diferensial linear orde satu. Diasumsikan bahwa:

$$
\frac{d y}{d t}=v
$$

dan

$$
\frac{d^{2} y}{d t^{2}}=\frac{d v}{d t}
$$

Hasil reduksi persamaan(4) menjadi sistem persamaan diferensial linear orde satu, yaitu persamaan(5) dan persamaan(6) sebagai berikut:

$$
\begin{gathered}
\frac{d y}{d t}=f_{1}(t, y, v)=v \\
\frac{d v}{d t}=f_{2}(t, y, v)=-\frac{c}{m} v-\frac{k_{t o t}}{m} y
\end{gathered}
$$

Persamaan(5) dan persamaan(6) selanjutnya diselesaikan dengan menggunakan metode Runge-Kutta orde empat untuk masalah nilai awal persamaan diferensial orde dua,maka diperoleh:

\section{Model Analysis of Motorcycle Suspension System Using the Fourth Order of Runge-Kutta Method}




$$
\begin{aligned}
& z_{1}= f_{1}\left(t_{i}, y_{i}, v_{i}\right) \\
&= v_{i} \\
& z z_{1}= f_{2}\left(t_{i}, y_{i}, v_{i}\right) \\
&=-\frac{c}{m} v_{i}-\frac{k_{t o t}}{m} y_{i} \\
& z_{2}= f_{1}\left(t_{i}+\frac{1}{2} h, y_{i}+\frac{1}{2} h \cdot z_{1}, v_{i}+\frac{1}{2} h \cdot z z_{1}\right) \\
&= v_{i}+\frac{1}{2} h \cdot z z_{1} \\
& z_{3}=f_{1}\left(t_{i}+\frac{1}{2} h, y_{i}+\frac{1}{2} h \cdot z_{2}, v_{i}+\frac{1}{2} h \cdot z z_{2}\right) \\
&=v_{i}+\frac{1}{2} h \cdot z z_{2} \\
& z z_{3}=f_{2}\left(t_{i}+\frac{1}{2} h, y_{i}+\frac{1}{2} h \cdot z_{2}, v_{i}+\frac{1}{2} h \cdot z z_{2}\right) \\
& \quad=-\frac{c}{m}\left(z_{3}\right)-\frac{k_{t o t}}{m}\left(y_{i}+\frac{1}{2} h \cdot z_{2}\right) \\
& z_{4}=f_{1}\left(t_{i}+h, y_{i}+h \cdot z_{3}, v_{i}+h \cdot z z_{3}\right) \\
&=v_{i}+h \cdot z z_{3} \\
& z z_{4}=f_{2}\left(t_{i}+h, y_{i}+h \cdot z_{3}, v_{i}+\frac{1}{2} h \cdot z z_{3}\right) \\
&=-\frac{c}{m}\left(z_{4}\right)-\frac{k_{t o t}}{m}\left(y_{i}+h \cdot z_{3}\right)
\end{aligned}
$$

Bentuk solusi menggunakan metode Rung-Kutta orde empat untuk masalah nilai awal persamaan diferensial orde dua yang didapatkan adalah:

$$
\begin{gathered}
y_{i+1}=y_{i}+\frac{1}{6}\left(z_{1}+2 z_{2}+2 z_{3}+z_{4}\right) h \\
v_{i+1}=v_{i}+\frac{1}{6}\left(z z_{1}+2 z z_{2}+2 z z_{3}+z z_{4}\right) h
\end{gathered}
$$

\begin{tabular}{|c|c|c|c|}
\hline$t_{i}$ & Iterasi Ke-i & Nilai $y_{i}$ & Nilai $v_{i}$ \\
\hline$t_{0}=0$ & 0 & $y_{0}=1$ & $v_{0}=0$ \\
\hline \multirow[t]{2}{*}{$1.10^{-5}$} & 1 & $y_{1}=y_{0}+\frac{1}{6}\left(z_{1}+2 z_{2}+2 z_{3}\right.$ & $v_{1}=v_{0}+\frac{1}{6}\left(z z_{1}+2 z z_{2}\right.$ \\
\hline & & $\left.+z_{4}\right) 10^{-5}$ & $\begin{array}{l}+2 z z_{3} \\
\left.+z z_{4}\right) 10^{-5}\end{array}$ \\
\hline \multirow[t]{2}{*}{$2.10^{-5}$} & 2 & $y_{2}=y_{1}+\frac{1}{6}\left(z_{1}+2 z_{2}+2 z_{3}\right.$ & $v_{2}=v_{1}+\frac{1}{6}\left(z z_{1}+2 z z_{2}\right.$ \\
\hline & & $\left.+z_{4}\right) 10^{-5}$ & $\begin{array}{l}+2 z z_{3} \\
\left.+z z_{4}\right) 10^{-5}\end{array}$ \\
\hline$\vdots$ & $\vdots$ & $\vdots$ & $\vdots$ \\
\hline
\end{tabular}

Iterasi dilakukan untuk $i=1$ sampai dengan $n=10^{6}$ sedemikan sehingga diperoleh nilai $f_{1}$ dan $f_{2}$, untuk setiap $i=0,1,2,3, \ldots, 10^{6}$ dan menggunakan interval waktu $\left[t_{0}, t_{n}\right]$ adalah $[0,10]$. Jarak antar partisi adalah $h=\frac{10}{10^{6}}=10^{-5}, \quad$ untuk setiap waktu $t_{i}=t_{0}+i h$ dan menggunakan syarat awal pada saat $t_{0}=0$, yaitu $y_{0}=1$ dan $v_{0}=0$. Oleh karena itu, secara umum perhitungan menggunakan metode Runge-Kutta orde empat untuk model sistem suspensi sepeda motor ditunjukkan pada Tabel 1.

Tabel 1. Metode Runge-Kutta Orde Empat Model Sistem Suspensi Sepeda Motor 
Tabel 1. Metode Runge-Kutta Orde Empat Model Sistem Suspensi Sepeda Motor (Lanjutan)

\begin{tabular}{|c|c|c|c|}
\hline \multirow[t]{4}{*}{10} & $10^{6}$ & $y_{10^{6}}=y_{10^{6}-1}+\frac{1}{6}\left(z_{1}+2 z_{2}\right.$ & $v_{10^{6}}=v_{10^{6}-1}+\frac{1}{6}\left(z z_{1}\right.$ \\
\hline & & $+2 z_{3}$ & $+2 z z_{2}$ \\
\hline & & $\left.+z_{4}\right) 10^{-5}$ & $+2 z z_{3}$ \\
\hline & & & $\left.+z z_{4}\right) 10^{-5}$ \\
\hline
\end{tabular}

Analisis Model Sistem Suspensi Sepeda Motor

Berdasarkan dari hasil pengamatan dan pengukuran yang dilakukan terhadap shockbreaker sepeda motor menggunakan percobaan damper tester, didapatkan hasil nilai konstanta 2 pegas dan nilai konstanta redaman pada Tabel 2.

Tabel 2. Hasil Penelitian Konstanta Pegas dan Konstanta Redaman

\begin{tabular}{cccc}
\hline No & $\begin{array}{c}\text { Massa/m } \\
(\mathrm{kg})\end{array}$ & $\begin{array}{c}\text { Konstanta } 2 \\
\text { Pegas } / k_{\text {tot }} \\
(\mathrm{N} / \mathrm{cm})\end{array}$ & $\begin{array}{c}\text { Konstanta } \\
\text { Redaman/c } \\
(\mathrm{Ns} / \mathrm{cm})\end{array}$ \\
\hline 1 & 10 & 1960 & 49 \\
2 & 25 & 2450 & 73,5 \\
3 & 53 & 2597 & 129,85 \\
4 & 61 & 2391,2 & 143,472 \\
\hline
\end{tabular}

Hasil analisis model suspensi berdasarkan penelitian yang dilakukan terhadap shockbreaker sepeda motor pada Tabel 2 mendapatkan model persamaan sistem suspensi dan model persamaan suspensi dengan redaman optimal untuk setiap beban yang diberikan, sebagai berikut:

1. Untuk $m=10 \mathrm{~kg}, k_{\text {tot }}=$ $1960 \mathrm{~N} / \mathrm{cm}$, dan

$$
c=49 \mathrm{Ns} / \mathrm{cm},
$$

dengan menggunakan Persamaan(4) maka model suspensi yang sesuai adalah

$$
10 y^{\prime \prime}+49 y^{\prime}+1960 y=0
$$

Persamaan diatas mempunyai persamaan karakteristik yaitu

$$
10 r^{2}+49 r+1960=0
$$

ambil $p=\frac{c}{2 m}=\frac{49}{2.10}=\frac{49}{20}=2,45$

$$
q=\sqrt{\frac{k_{\text {tot }}}{m}}=\sqrt{\frac{1960}{10}}=\sqrt{196}=14
$$

$D=p^{2}-q^{2}=(2,45)^{2}-(14)^{2}=$ $-18,998$

karena $D<0$, dalam kasus ini sistem suspensi termasuk dalam kriteria under damped sehingga sepeda motor akan ber-oksilasi beberapa saat sebelum mencapai keadaan setimbang berakibat pengendara kurang nyaman. Untuk mendapatkan kenyamanan berkendara dari kasus ini, konstanta redaman harus mendekati redaman yang optimal, maka redaman optimal untuk $m=10 \mathrm{~kg}$, $k_{\text {tot }}=1960 \mathrm{~N} / \mathrm{cm}$ adalah

$$
\begin{gathered}
c=2 m \sqrt{\frac{k_{t o t}}{m}}=2.10 \sqrt{\frac{1960}{10}}=20 \cdot \sqrt{196} \\
=20.14=280
\end{gathered}
$$


oleh karena itu model persamaan suspensi dengan redaman optimal untuk $m=10 \mathrm{~kg}, k_{\text {tot }}=1960 \mathrm{~N} / \mathrm{cm}$ adalah $c=280 \mathrm{Ns} / \mathrm{cm}$, adalah

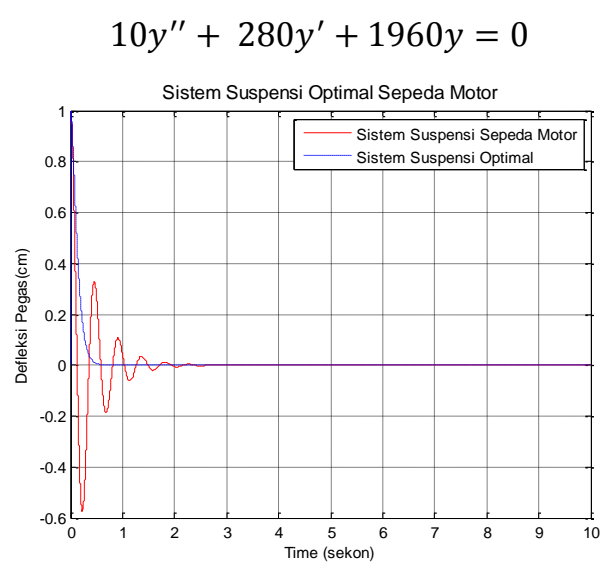

Gambar 2 Grafik sistem suspensi dengan redaman optimal untuk $\mathrm{m}=10 \mathrm{~kg}, \mathrm{k}_{\mathrm{tot}}=1960$ $\mathrm{N} / \mathrm{cm}$, dengan $\mathrm{v}(0)=0, \mathrm{y}(0)=1$

Gambar 2 menunjukkan bahwa dengan kecepatan nol karena kendaraan dalam keadaan diam dan jika benda dipindahkan sejauh 1 satuan mengakibatkan suspensi akan berhenti bergetar atau getaran berangsur-angsur mengecil dan mencapai keadaan setimbang pada waktu $t<3$ detik untuk $c=49 \mathrm{Ns} / \mathrm{cm}$ (redaman sepeda motor), sedangkan untuk $c=280 \mathrm{Ns} / \mathrm{m}$ (redaman optimal) getaran cepat berhenti dan mencapai keadaan setimbang pada waktu $t<1$ detik. Dengan cara yang sama analisis dilakukan terhadap 3 massa beban selanjutnya, hasil analisis model sistem suspensi untuk 4 massa beban ditujukkan pada Tabel 3.

Tabel 3. Hasil Analisis Model Sistem Suspensi Sepeda Motor

\begin{tabular}{|c|c|c|c|}
\hline No & $\begin{array}{l}\text { Massa } / m \\
(\mathrm{~kg})\end{array}$ & Model Sistem Suspensi & Model Sistem Suspensi Optimal \\
\hline 1 & 10 & $10 y^{\prime \prime}+49 y^{\prime}+1960 y=0$ & $10 y^{\prime \prime}+280 y^{\prime}+1960 y=0$ \\
\hline 2 & 25 & $25 y^{\prime \prime}+73,5 y^{\prime}+2450 y=0$ & $25 y^{\prime \prime}+494,975 y^{\prime}+2450 y=0$ \\
\hline 3 & 53 & $53 y^{\prime \prime}+129,85 y^{\prime}+2597 y=0$ & $53 y^{\prime \prime}+742 y^{\prime}+2597 y=0$ \\
\hline 4 & 61 & $61 y^{\prime \prime}+143,472 y^{\prime}+2391,2 y=0$ & $61 y^{\prime \prime}+143,472 y^{\prime}+2391,2 y=0$ \\
\hline
\end{tabular}

Berdasarkan hasil analisis pada Tabel 3 menunjukkan bahwa sistem suspensi belum optimal, dapat disimpulkan rata-rata sistem suspensi bergetar cukup lama karena redaman yang terjadi jauh dari redaman optimal untuk setiap massa $(m)$ yang diberikan. Jadi semakin besar massa yang diberikan maka semakin cepat waktu yang dibutuhkan untuk mencapai posisi kesetimbangan.

\section{Model Analysis of Motorcycle Suspension System Using the Fourth Order of Runge-Kutta Method}




\section{Perbandingan Hasil Analisis Model Sistem Suspensi Sepeda Motor}

Perbandingan analisis suspensi sepeda motor dengan metode analitik dan metode Runge-Kutta orde empat dilakukan dengan menggunakan Matlab pada interval waktu $[0,10]$, untuk setiap model sistem suspensi sepeda motor.

1. Hasil simulasi menggunakan Matlab pada interval waktu $[0,10]$ pada saat $m=10 \mathrm{~kg}, \quad k_{\text {tot }}=1960 \mathrm{~N} / \mathrm{cm}, \quad$ dan $c=49 \mathrm{Ns} / \mathrm{cm}, \quad$ diperoleh bahwa perubahan panjang pegas adalah $0,1 \mathrm{~cm}$ dengan redaman optimal untuk $m=$ $10 \mathrm{~kg}, \quad k_{\text {tot }}=1960 \mathrm{~N} / \mathrm{cm}, \quad$ dan $\quad c=$ $280 \mathrm{Ns} / \mathrm{cm}$, sehingga redaman yang terjadi untuk model ini belum optimal.

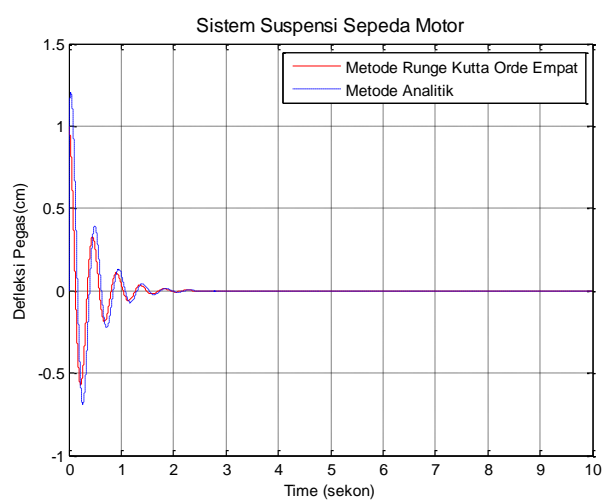

Gambar 3 Grafik perbandingan metode analitik dan metode Runge-Kutta orde empat untuk $\mathrm{m}=10 \mathrm{~kg}, \mathrm{k}_{\mathrm{tot}}=1960 \mathrm{~N} / \mathrm{cm}$, dan $\mathrm{c}=49 \mathrm{Ns} / \mathrm{cm}$

Gambar 3 menunjukkan bahwa grafik solusi metode Runge-Kutta orde empattidak jauh berbeda dengan grafik solusi metode analitiknya, pada perhitungan Matlab tercatat bahwa waktu yang diperlukan metode analitik untuk menganalisis adalah 1,830 detik sedangkan metode Runge-Kutta orde empat hanya 1,706 detik. Suspensi beroksilasi dengan regangan maksimum yang dicapai adalah sekitar 1,5 cm, selanjutnya berangsur-angsur mengecil dan mencapai keadaan setimbang pada waktu $t<3$ detik.

Gambar 4 menunjukkan bahwa galat langkah perbandingan metode analitik dan metode Runge-Kutta orde empat pada model sistem suspensi untuk $m=10 \mathrm{~kg}, \quad k_{\text {tot }}=1960 \mathrm{~N} / \mathrm{cm}$, dan $c=49 \mathrm{Ns} / \mathrm{cm}$ semakin lama galat akan semakin kecil dan mendekati nol mulai pada waktu $t=3$ detik.

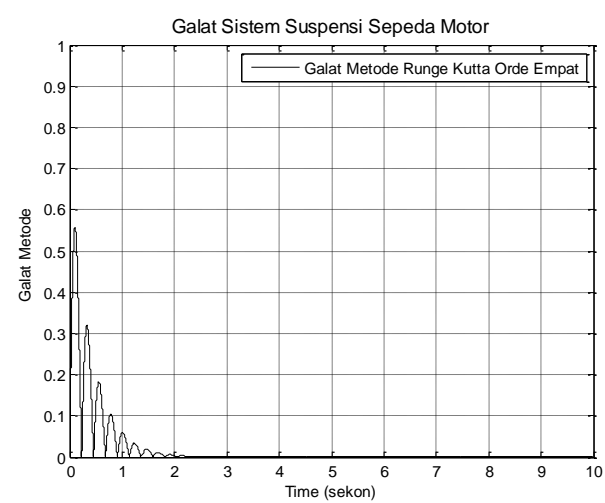

Gambar 4 Grafik galat perbandingan metode analitik dan metode Runge-Kutta orde empat untuk $\mathrm{m}=10 \mathrm{~kg}, \mathrm{k}_{\mathrm{tot}}=1960 \mathrm{~N} / \mathrm{cm}$, dan $\mathrm{c}=49$ $\mathrm{Ns} / \mathrm{cm}$

Berdasarkan gambar 4 dan perhitungan Matlab galat rata-rata model sistem ini adalah 0,019 artinya metode Runge-Kutta merupakan metode yang baik untuk menyelesaikan persamaan model sistem suspensi 
sepeda Motor untuk $m=10 \mathrm{~kg}, \quad$ massa beban selanjutnya, hasil $k_{\text {tot }}=1960 \mathrm{~N} / \mathrm{cm}$, dan $c=49 \mathrm{Ns} / \mathrm{cm}$. perbandingan analisis suspensi sepeda Dengan cara yang sama perbandingan motor dengan metode analitik dan analisis suspensi sepeda motor dengan metode analitik dan metode Rungemetode Runge-Kutta orde empat untuk 4 massa beban ditujukkan pada tabel 4.

Kutta orde empat dilakukan terhadap 3

Tabel 4. Hasil perbandingan analisis suspensi sepeda motor dengan metode analitik dan metode RungeKutta orde empat

\begin{tabular}{cccc}
\hline Model Sistem Suspensi & Galat Metode & $\begin{array}{c}\text { Waktu Analisis } \\
\text { Metode Analitik }\end{array}$ & $\begin{array}{c}\text { Waktu Analisis Metode } \\
\text { Runge-Kutta Orde } \\
\text { Empat }\end{array}$ \\
\hline $\begin{array}{r}10 y^{\prime \prime}+49 y^{\prime}+1960 y \\
=0\end{array}$ & 0,019 & 1,830 & 1,706 \\
$25 y^{\prime \prime}+73,5 y^{\prime}+2450 y$ & 0,044 & 1,853 & 1,632 \\
$=0$ & 0,068 & 1,842 & 1,681 \\
$53 y^{\prime \prime}+129,85 y^{\prime}$ & & & 1,674 \\
$+2597 y=0$ & 0,087 & 1,839 & \\
$61 y^{\prime \prime}+143,472 y^{\prime}$ & & & \\
$+2391,2 y=0$ & & & \\
\hline
\end{tabular}

Berdasarkan hasil perbandingan analisis suspensi sepeda motor dengan metode analitik dan metode RungeKutta orde empat untuk 4 massa beban pada Tabel 4, dapat diketahui bahwa galat yang dihasilkan oleh metode Runge-Kutta orde empat adalah kurang dari 0,1 dan waktu analisis untuk setiap model menggunakan metode RungeKutta lebih cepat daripada metode analitik. Oleh karena itu, dapat disimpulkan bahwa metode RungeKutta orde empat merupakan metode yang cukup baik untuk analisis model sistem suspensi sepeda motor.

\section{Kesimpulan}

Dari pembahasan yang telah dipaparkan penulis, maka kesimpulan yang dapat diambil adalah Persamaan diferensial dari model matematika sistem suspensi pada sepeda motor untuk $m=10 \mathrm{~kg}, \quad k_{\text {tot }}=1960 \mathrm{~N} / \mathrm{cm}$, $c=49 \mathrm{Ns} / \mathrm{cm}$ adalah $10 y^{\prime \prime}+49 y^{\prime}+$ $1960 y=0$, untuk $m=25 \mathrm{~kg}, k_{\text {tot }}=$ $2450 \mathrm{~N} / \mathrm{cm}, c=73 \mathrm{Ns} / \mathrm{cm}$ adalah $25 y^{\prime \prime}+73,5 y^{\prime}+2450 y=0$, 
untuk $m=53 \mathrm{~kg}, k_{\text {tot }}=2597 \mathrm{~N} / \mathrm{cm}$, $c=129,85 \mathrm{Ns} / \mathrm{cm}, \quad$ adalah $53 y^{\prime \prime}+$ $129,85 y^{\prime}+2597 y=0, \quad$ dan $\quad$ untuk $m=61 \mathrm{~kg}, \quad k_{\text {tot }}=2391,2 \mathrm{~N} / \mathrm{cm}$, $c=143,472 \mathrm{Ns} / \mathrm{cm}$ adalah $61 y^{\prime \prime}+$ $143,472 y^{\prime}+2391,2 y=0 . \quad$ Model sistem suspensi sepeda motor menggunakan solusi persamaan diferensial pada kondisi suspensi under damped (redaman subkritis atau redaman rendah), tingkat redaman sistem suspensi pada sepeda motor optimal, dan tingkat galat metode Runge-Kutta orde empat dengan metode analitik cukup kecil, yaitu kurang dari 0,1 dengan waktu analisis untuk setiap model suspensi menggunakan metode Runge-Kutta lebih cepat daripada metode analitik. Oleh karena itu metode Runge-Kutta orde empat adalah metode yang cukup akurat untuk analisis model sistem suspensi sepeda motor.

\section{Daftar Pustaka}

Atkinson, K.E, Han, W, \& Stewart, D, 2009, Numerical solution of ordinarry differential equations, 70, John Wiley \& Sons, Inc, Lowa City, Lowa.

Ayu Aulia Hakim, 2017, Pemodelan dan analisis pengaruh perubahan parameter variable orifice sistem suspensi hidrolik terhadap gaya redam yang dihasilkan dan respon dinamis penumpang pada sepeda motor honda beat 2009, Skripsi, Jurusan Teknik Mesin Institut Sepuluh Nopember, Surabaya.

Bhasha, A.C, Reddy, N.V, and Rajnaveen, B, 2017, Design and analysis of shock absorber, International research juornal of engineering and technology (IRJET), 2017, 04, 201-207.

Denton, Tom, 2012, Advenced automotive fault diagnosis $\left(3^{\text {nd }}\right.$ ed.), 293, Rotledge, New York, USA.

Ika Nurul Hanifah, 2013, Analsis model getaran pegas teredam dengan metode adams-basforthmoulton dan runge-kutta, Skripsi, Jurusan Matematika Universitas Jember, Jember.

Ismi Widyaningrum, 2012, Metode multiple time scale untuk penyelesaian persamaan diferensial tak linear dari sistem double shockbreaker pada sepeda motor, Skripsi, tidak dipublikasikan, Universitas Negeri Semarang, Semarang.

Jazar, R.N, 2008, Vehicle Dynamics: theory and application, 791 192, Spinger, New York, USA.

Kartono, 2012, Persamaan diferensial biasa: model matematika fenomena perubahan, 163, Graha Ilmu, Yogyakarta, Indonesia. ISBN 978-979-756810-8

Karyasa, T.B, 2011, Dasar dasar getaran mekanis, 62, C.V Andi Offet, Yogyakarta, Indonesia. ISBN 978-979-29-1683-6. 
M Fauzi Rahman, 2017, Pemodelan dan analisis pengaruh luasan sisi kompresi dan ekspansi dengan variasi diameter piston, orifice, piston rod terhadap gaya redam dan respon dinamis sepeda motor yamaha mio j, Skripsi, Jurusan Teknik Mesin Institut Sepuluh Nopember, Surabaya.

Martande, S, Jangale, Y.N, Motgi, N.S, 2013, Design and analysis of shock absorber. International juornal of application or inovation in engineering \& management (IJAIEM), 2013, 02, 195-199.

Muhamad Rai Anggara Putra, 2017, Pemodelan dan analisis pengaruh penggunaan adaptive shock absorber menggunakan variabel orifice terhadap karakteristik gaya redam dan respon dinamis kendaraan, Skripsi, Jurusan Teknik Mesin Institut Sepuluh Nopember, Surabaya.

Munir, Rinaldi, 2010, Metode numerik (revisi ketiga), 366, Informatika, Bandung, Indonesia. ISBN 978602-8758-08-6.

Pauliza, Oza, 2008, Fisika kelompok teknologi dan kesehatan untuk sekolah menengah kejuruan kelas X( jilid 1), 140, Grafindo Media Pratama, Bandung, Indonesia. ISBN 978-602-000175-3.

Peceliunas, Robertas, 2005, Experimen research vehicle oscillation in the case of changeable deceleration, Transport, 2005, 20, 171-175.

Renny Faridah, 2015, Analisis model getaran pegas teredam dengan metode Runge-Kutta gill dan milne, Skripsi, Jurusan Matematika Universitas Jember, Jember.

Sutantra, I N. dan Sampurno, B., 2010, Teknologi otomotif (edisi kedua), 38, Guna Widya Printing, Surabaya, Indonesia. ISBN 979545-052-2.

Wakid, Mukhamad, 2011, Sistem suspensi kendaraan ringan, 15 16, Mentari Pustaka, Yogyakarta, Indonesia. ISBN 978-602-8231-56-5.

Meirianti. 2016. Pengaruh Kemiskinan, Belanja Pemerintah Bidang Pendidikan, Kesehatan dan Ekonomi Terhadap Tingkat IPM di 38 Kabupaten/Kota Provinsi Jawa Timur, 2010-2014. Tugas Akhir. Yogyakarta : Universitas Gajah Mada 